\title{
Determination of water soluble vitamins in Egyptian Honey by RP-HPLC
}

\author{
Ahmad M. Farag ${ }^{1 *}$, Mahmoud S. Rizk ${ }^{1 * *}$, Hamdy A. El-Bassel ${ }^{2}$, Mona H. Youssif ${ }^{1 * *}$ \\ and Fatehy M. Abdel-Haleem ${ }^{1}$ \\ 1- Department of Chemistry, Faculty of Science, Cairo University, Giza 12613, Egypt. \\ afarag49@yahoo.com,ms_rizk@yahoo.com,fatehy@sci.cu.edu.eg \\ 2-Department of Nutritional Biochemistry and Metabolism, National Nutrition Institute, \\ Cairo, Egypt.h.elbassel17@gmail.com, \\ **mona.hanafy83@gmail.com
}

\begin{abstract}
The purpose of this study is to evaluate water soluble vitamins $\left(C, B_{1}, B_{2}, B_{3}, B_{6}, B_{9}\right.$ and $\mathrm{B}_{12}$ ) in honey from honey bees feed on Spring flowers, Sweet marjoram, Sun flower, Clover flowers, Citrus fruits and Black seed using gradient RP-HPLC methods with PDA detector. The highest levels of vitamins $\mathrm{C}, \mathrm{B}_{1}, \mathrm{~B}_{2}$, and $\mathrm{B}_{6}$ were observed in citrus fruits honey, sunflower honey, black seed honey and spring flower honey, respectively. The highest levels in vitamins $\mathrm{B}_{3}, \mathrm{~B}_{9}$ and $\mathrm{B}_{12}$ were observed in sweet marjoram honey, where the lowest levels for these vitamins were observed in clover flower honey. The lowest levels for vitamins $\mathrm{B}_{2}$ and $\mathrm{B}_{9}$ were observed in black seed honey. The lowest levels for vitamins $\mathrm{C}$ and $\mathrm{B}_{1}$ were observed in spring flower honey and citrus fruits, respectively. These results indicated the presence of a significant difference in water soluble vitamins content depending on the type of Egyptian honey.
\end{abstract}

Key words: HPLC, PDA, Water soluble vitamins, Egyptian honey.

\section{INTRODUCTION}

Vitamins are organic nutrients required by the body to ensure normal growth and metabolism (Semba, 2012). Vitamins are classified as micronutrients which exist in food in small quantities, and macronutrients as protein, carbohydrates and fats (Rucker et al., 2007). Although vitamins are essential for the prevention of a number of diseases and the maintenance of good health, the human body cannot make vitamins and it must get them from different foods which are considered as vitamin supply (Semba, 2012; Rucker et al., 2004, 2007). The importance of vitamins in nutrition was understood in the 1920s and 1930s, where lack of them can cause various diseases in humans, and small concentrations are required to maintain good health (Semba, 2012; Rucker et al., 2004, 2007). Because of the critical role of vitamins in nutrition, qualitative and quantitative analyses are important issues and a challenging task for food manufacturers.

Water soluble vitamins are thiamine $\left(\mathrm{B}_{1}\right)$, riboflavin $\left(\mathrm{B}_{2}\right)$, pyridoxine HCL $\left(\mathrm{B}_{6}\right)$, cyanocobalamin $\left(\mathrm{B}_{12}\right)$, nicotinic acid $\left(\mathrm{B}_{3}\right)$, folic acid $\left(\mathrm{B}_{9}\right)$, pantothenic acid $\left(\mathrm{B}_{5}\right)$, and vitamin $\mathrm{C}$. Complex vitamins $\mathrm{B}$ and vitamin $\mathrm{C}$ cannot be stored in human tissues. Their excess is excreted with urine but excess amounts of fat soluble vitamins stored in adipose tissues and in the liver (Rucker et al., 2004).

Honey is a sweet food made by bees from the flowers nectar or honeydew droplets (Ajibola et al., 2012). It has been found to be beneficial to people suffering from anemia (Ajibola et al., 2007) where it improves hemoglobin concentration and increases erythrocyte count and elevated hematocrit in the honey eaters. Also, it was reported that honey enhanced hematology and immune response in rats fed with $10 \%$ honeydew honey supplemented diet (Chepulis and Compl, 2007). Subjects 
Ahmad M. Farag et al.

administered with two honey treatments in a Californian study show that honey eaters have the benefit of haematoprotection in addition to blood proliferation (Schramm et al., 2003). The researchers observed that the aqueous portion of the blood (plasma) is protected by honey. This agrees with the fact that most of the antioxidant components in processed honey are water soluble.

In summarizing the facts that honey can be considered a satisfactory immuno-nutrient, some workers opine that the oral administration of natural honey can stimulate and increase the production of antibody during primary and secondary immune responses against the T-cells of the thymus-dependent as well as the thymus independent antigens (Al-Waili and Haq, 2004). Honey essentially consists of a supersaturated solution mostly from fructose and glucose; it contains about 90\% carbohydrates and minor substances as polyphenols, enzymes, organic acids, flavonoids, minerals, amino acids and proteins, but the water-soluble vitamins are the main products (Abdel-Haleem et al., 2016 ; Rizk and Abdel-Haleem, 2010). Different analytical methods could be used for the determination of the different species, including drugs and vitamins (Abdel-Haleem et al., 2016; Rizk and Abdel-Haleem, 2010). Electrochemical methods are of the best methods, as it is simple, rapid for routine analysis, costeffective, applied in a wide concentration range and of high sensitivity (AbdelHaleem et al., 2016; Rizk et al., 2017).

However, in case of real samples that may include vitamins and proteins, adsorption to the electrode surface is a serious problem (Buhlmann et al., 1997). On the other hand, the common official analytical method is non-specific, tedious and time consuming as these methods involve pretreatment of the sample through physical, biological and complex chemical reactions to eliminate the interferences found (Indyk et al., 2002). it followed by individual methods for each different vitamin. The determinations of vitamins B and vitamin $\mathrm{C}$ in food were performed by spectrophotometry (Revanasiddappa and Veena, 2008), electrochemical method (Marszall et al., 2005; Mimica et al., 2002), capillary electrophoresis (Fotsing et $a l ., 1997)$ and HPLC for more complicated mixtures of two or more vitamins (Ramla, 2016; Rokayya et al., 2014; Ciulu et al., 2011; Ekinci \& Kadakal, 2005) with gradient elution program. The separations were occurred on normal-phase, ionpairing and reversed-phase chromatography columns.

In the present work, a simultaneous determination of $B$ complex vitamins $\left(B_{1}\right.$, $\mathrm{B}_{3}, \mathrm{~B}_{6} \mathrm{~B}_{9}, \mathrm{~B}_{2}$ and $\mathrm{B}_{12}$ ) and vitamin $\mathrm{C}$ in honey was proposed using a simple gradient program by setting the wavelength at $272 \mathrm{~nm}$. Also, the chromatographic system developed clearly separates the seven analytes from their degradation products.

\section{MATERIALS AND METHODS}

\section{Apparatus and chemicals}

HPLC (Shimadzu LC-20, Japan), Centrifuge (Pro-Research, UK), pH-meter (Jenway3310, British), Mixer (Falk, Germany) and Ultra-sonic bath (Elma, Germany) were used in this study.

Honey samples were collected from the Faculty of Agriculture, Cairo University. Samples were collected in glass bottles and stored in dark at $25^{\circ} \mathrm{C}$. Honey samples were spring flowers, sweet marjoram, Sun flower, clover flowers, citrus fruits and Black seed.

All chemicals were of the highest purity available analytical grade and all solvents in this study were HPLC-grade and obtained from sigma Aldrich (Germany).

\section{Preparation of vitamins solution}

The mixtures of water soluble vitamins were prepared by dissolving 200 $\mathrm{mg}$ of Thiamine hydrochloride, nicotinic acid, folic acid, pyridoxine hydrochloride, 


\section{Determination of water soluble vitamins in Egyptian Honey by RP-HPLC}

vitamin $\mathrm{C}$, cyanocobalamin, riboflavin in $1 \mathrm{~L}$ of $4 \%$ trichloro acetic acid (TCA). The standard solution was kept in the dark at 4 ${ }^{\circ} \mathrm{C}$ and was prepared fresh daily. This stock was used for preparation of more dilute solutions by appropriate dilutions.

\section{a. Extraction of samples}

Five grams of homogenized honey were weighed, completed to the mark in 10 $\mathrm{ml}$ measured flask by using $4 \%$ TCA, mixed for $5 \mathrm{~min}$, centrifugated for $15 \mathrm{~min}$ (6000 RPM), filtered by using $0.45 \mu \mathrm{m}$ filter membrane and injected in HPLC instrument.

\section{b- Method}

High performance liquid chromatographic method was used for the determination of water-soluble vitamins. Separation was performed on a Waters spherisorb ODS2 $(250 \mathrm{~mm} \times 4.6 \mathrm{~mm}, 5 \mu \mathrm{m})$ column. Gradient elution was performed with a mobile phase consisting of $0.2 \mathrm{~g}$ heptane-1-sulfonic acid sodium salt in deionized water: methanol (90:10, v/v) of $\mathrm{pH} 3$ (solvent $\mathrm{A}$ ), and $0.2 \mathrm{~g}$ heptane-1sulfonic acid sodium salt in deionized water: methanol $(30: 70, \mathrm{v} / \mathrm{v})$ of $\mathrm{pH} 3$

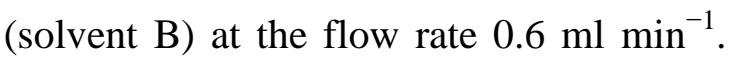
Starting with $100 \%$ solvent A then the composition was changed gradually during next 30 min to reach $100 \%$ of solvent $B$. The measurements were carried out at wavelength $272 \mathrm{~nm}$, at room temperature with $0.6 \mathrm{ml} \mathrm{min}^{-1}$ flow rate.

\section{RESULTS AND DISCUSSION}

Honey consists of a mixture of complex compounds (flavonoids, phenolic acids and amino acid); so, separation methods as HPLC with UV-VIS detectors or PDA detector, are the most suitable for these complex compounds.

\section{Selection of the appropriate column}

There were many different types of chromatographic columns that have been used for separation of some water-soluble vitamins; intersil ODS $(250 \mathrm{~mm} \times 4.6 \mathrm{~mm}$ $\times 5 \mu \mathrm{m})$ and a waters spherisorb ODS2 $(250 \mathrm{~mm} \times 4.6 \mathrm{~mm} \times 5 \mu \mathrm{m})$ chromatographic columns were tested (Figs. 1A \& B). The present study showed that Waters spherisorb ODS2 $(250 \mathrm{~mm} \times$ $4.6 \mathrm{~mm} \times 5 \mu \mathrm{m})$ was good for separation of the seven analytes in the chromatogram (Fig.1B).

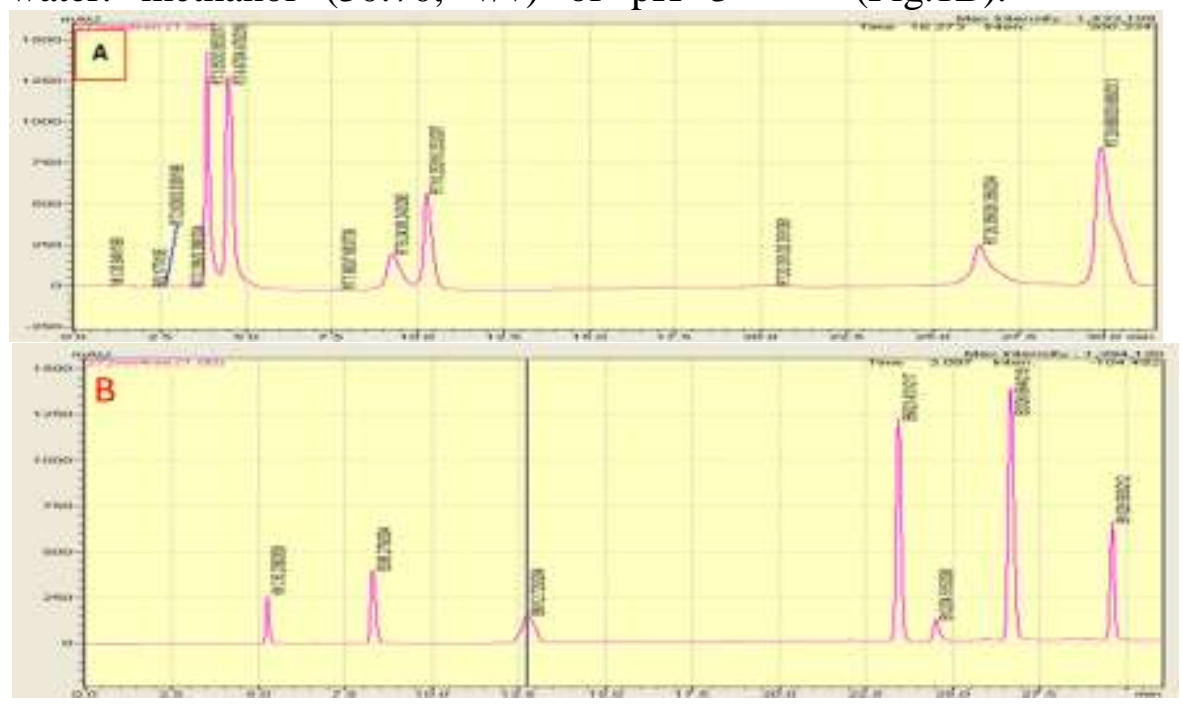

Fig. 1: Chromatogram for vitamin $\mathrm{c}$ and different vitamins $B$ using intersil ODS column (A), and water spherisorb ODS2 column (B). 
Ahmad M. Farag et al.

Resolution measurement of waters spherisorb ODS2 column

The results listed in Table (1) show the column parameters for an optimum separation of water soluble vitamins. The capacity factor $\left[\mathbf{K}=\left(\mathbf{R} \mathbf{T}_{\mathbf{1}}-\mathbf{R} \mathbf{T}_{\mathbf{0}}\right) / \mathbf{R} \mathbf{T}_{\mathbf{0}}\right]$,

separation factor $\mathbf{S}=\mathbf{k}_{\mathbf{2}} / \mathbf{k}_{\mathbf{1}}$ and the resolution $\left[\mathbf{R}=\mathbf{2}\left(\mathbf{R} \mathbf{T}_{\mathbf{2}}-\mathbf{R} \mathbf{T}_{\mathbf{1}}\right) /\left(\mathbf{W}_{\mathbf{2}}+\mathbf{W}_{\mathbf{1}}\right)\right]$ were ranged in (19.9), (1.1-2) and (1.5-7), respectively, for water soluble vitamins separated on Waters spherisorb ODS2 column.

Table 1: Column parameters for an optimum separation of water soluble vitamins.

\begin{tabular}{lllllll}
\hline Compound & RT min & $\mathbf{k}$ & $\mathbf{S}$ & $\mathbf{W}$ & $\mathbf{N}$ & $\mathbf{R}$ \\
\hline Vit C & 5.1 & 1.0 & ---- & 0.6 & 1156 & ---- \\
Vit $\mathrm{B}_{3}$ & 8.0 & 2.0 & 2.0 & 0.6 & 2844 & 4.8 \\
Vit $_{6}$ & 12.2 & 3.7 & 1.8 & 2.0 & 595 & 3.2 \\
Vit $_{9}$ & 22.0 & 7.46 & 2.0 & 0.8 & 12100 & 7.0 \\
Vit $_{12}$ & 24.5 & 8.4 & 1.1 & 1.0 & 7744 & 2.7 \\
Vit $\mathrm{B}_{2}$ & 26.0 & 9.0 & 1.1 & 1.0 & 10816 & 1.5 \\
Vit B $_{1}$ & 28.5 & 9.9 & 1.1 & 1.0 & 12996 & 2.5 \\
\hline
\end{tabular}

Retention times (RT), capacity factors (K), separation factors(S), Column efficiency (N), Resolution (R) and peak width (W) show optimum condition for separation of water soluble vitamins.

The column selectivity, originally called the separation factor $(\mathrm{S})$, is defined as the ratio of the capacity factors of two adjacent peaks. When the value of $S \geq 1$, this means that we obtained base lines separation for all the eluted mixtures (Lioyd et al., 2011). A resolution value of 1.5 or greater between two peaks will ensure that the sample components are well separated (Lioyd et al., 2011). The separation mechanism in Waters spherisorb ODS2 column depends on the hydrophobic binding interaction between immobilized hydrophobic ligand of the stationary phase and the $\mathrm{R}$ groups attached to the organic compound. The different values of retention times due to interaction between different $\mathrm{R}$ groups of organic compounds and two octadecyl groups of the stationary phase governed the mechanism of the retention time (Lioyd $e t$ al., 2011).

\section{Optimization for separation of some water soluble vitamins.}

The optimization work mainly depends on the choice of UV wavelength and the addressed program of the chromatographic elution, to maximize both resolution and sensitivity. So, the contents of mobile phases were $0.2 \mathrm{~g}$ heptane-1sulfonic acid sodium salt in deionized water: methanol (90:10, v/v) adjusted to $\mathrm{pH} 3$ (solvent $\mathrm{A}$ ), and $0.2 \mathrm{~g}$ heptane-1sulfonic acid sodium salt in deionized water: methanol (30:70, v/v) adjusted to pH 3 (solvent B).

Table 2: Three different gradient profiles for simultaneous vitamins separation by RP-HPLC.

\begin{tabular}{|c|c|c|c|c|c|c|c|c|c|c|}
\hline \multirow{2}{*}{$\begin{array}{c}\text { Time } \\
\text { Solvent }\end{array}$} & \multicolumn{4}{|c|}{ Gradient-1(A) } & \multicolumn{3}{c|}{ Gradient-2(B) } & \multicolumn{3}{c|}{ Gradient-3(C) } \\
\cline { 2 - 12 } & 0 & 15 & 30 & 50 & 0 & 15 & 37 & 0 & 15 & 30 \\
\hline solvent A\% & 90 & 40 & 10 & 10 & 92 & 47 & 3 & 100 & 50 & 0 \\
\hline Solvent B \% & 10 & 60 & 90 & 90 & 8 & 53 & 97 & 0 & 50 & 100 \\
\hline
\end{tabular}

It was obvious from Table (2) and Figure (2) that gradient-3 was preferred because a resolution value of 1.5 or greater between two adjacent peaks will ensure that the sample components are well separated to a degree at which the area of each peak may be accurately measured and give vitamin $\mathrm{C}$ and six vitamins $\mathrm{B}$ with good resolution. 
Determination of water soluble vitamins in Egyptian Honey by RP-HPLC
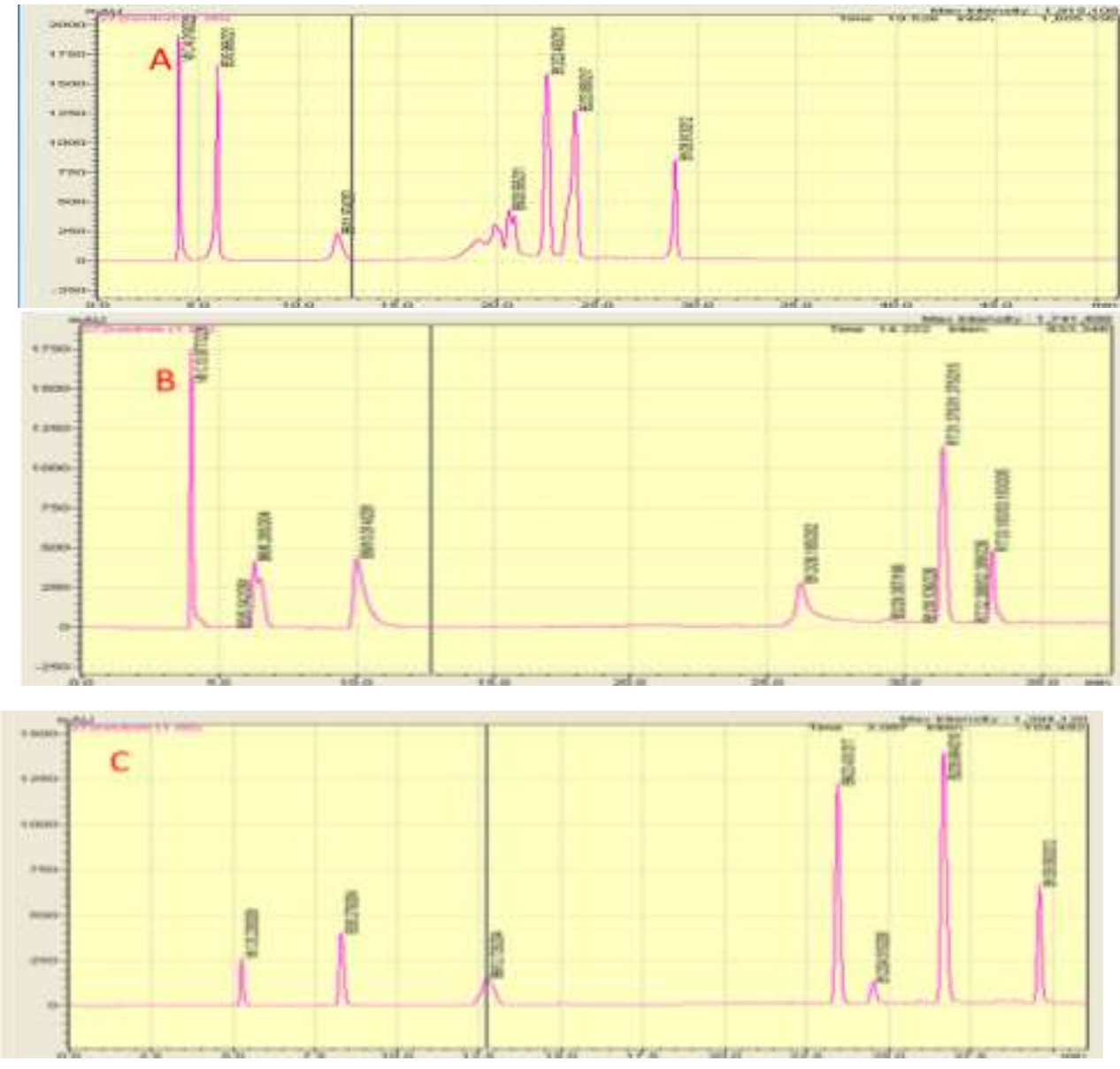

Fig. 2: Chromatograms for RP-HPLC simultaneous vitamins separation gradiant-1(A), gradiant-2 (B) and gradiant-3 (C)

The effect of $\mathrm{pH}$ on the retention time of some water-soluble vitamins standards

In the present study the effect of different $\mathrm{pH}$ values on the retention time of standards was studied by using two solvents (A and $\mathrm{B}$ ); the $\mathrm{pH}$ of these solvents varied between ranges $2-7$ by adding a few drops of sodium hydroxide or acetic acid. It was not possible to cover $\mathrm{pH}$ range less than 2 and more than 8 due to instability of the packing over the region since alkaline solution dissolves the silica support and at low $\mathrm{pH}$ breaks the Si-O linkage.

The curves show change of retention time of some water-soluble vitamins with the change of $\mathrm{pH}$ of mobile phase. The decrease in the retention time with $\mathrm{pH}$ increase is in accordance with the faint acidic $\mathrm{pH}$ of the honey (3-6), which maintains the honey acidic groups in the non-dissociated neutral form that in turn facilitates the interaction with the column of the low polarity and increase the retention time (Molnar, 1996). The optimum $\mathrm{pH}$ obtained for best separation of water soluble vitamins is at $\mathrm{pH} \mathrm{3}$, because a resolution value of 1.5 or greater between two adjacent peaks will ensure that the sample components are well separated to a degree at which the area of each peak may be accurately measured (Fig.3). 
Ahmad M. Farag et al.

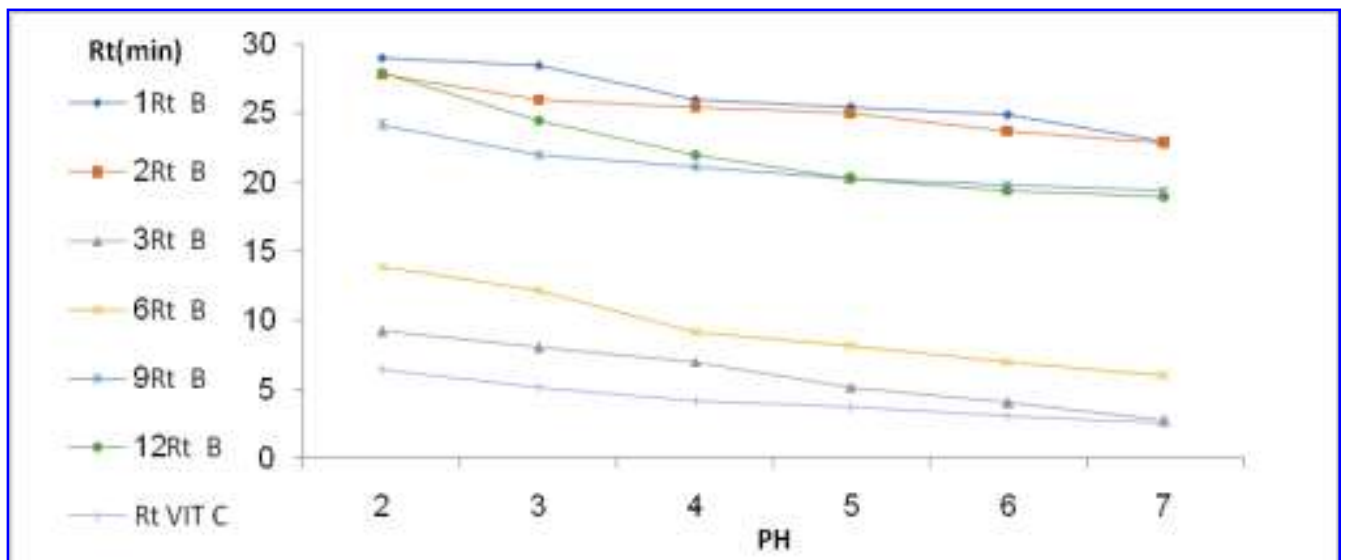

Fig 3: Effect of $p H$ on retention time (RT) of soluble vitamins; $B_{1}, B_{2}, B_{12}, B_{9}, B_{6}, B_{3}$ and vit. $C$.

\section{The effect of flow rate on separation of}

water soluble vitamins

HPLC column is affected with change of flow rate because of changes of pressure and analysis time (Ciulu et al., 2011). A high flow rate may reduce the analysis time but may adversely affect the quality of chromatography, as it may not permit sufficient time for analyte separation and interact with stationary phase. Table (4) and Figure (4) show that, the retention time of water soluble vitamins changes with the flow rate $(0.6$ $\mathrm{ml} / \mathrm{min}$ to $1.2 \mathrm{ml} / \mathrm{min}$ ); acceptable flow rate is $(0.6 \mathrm{ml} / \mathrm{min})$ which gave resolution value of 1.5 or greater between two adjacent peaks and this indicated that the sample components are well separated, but high flow rate not sufficient for separation of folic acid and cyanocoblamin, thiamin and riboflavin, and ascorbic acid and nicotinic acid, and give resolution value less than 1 between two adjacent peaks.

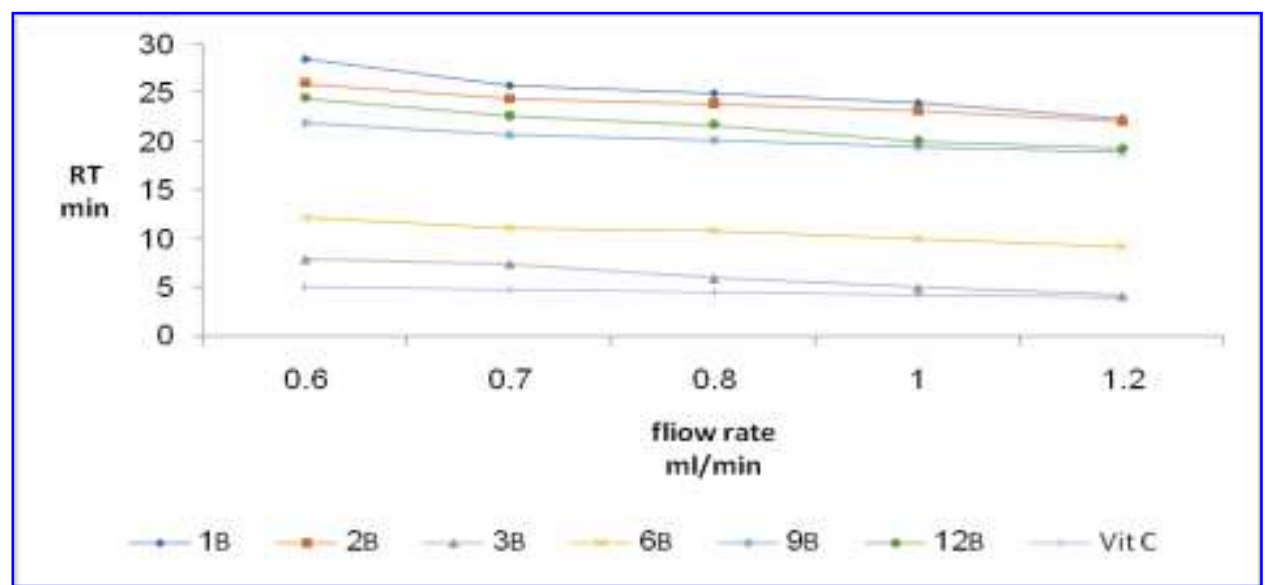

Fig 4: retention time as a function of flow rate for some water soluble vitamins; $B_{1}, B_{2}, B_{12}, B_{9}, B_{6}, B_{3}$ and) vit. $C$.

\section{Calibration curves and method validation}

The calibration curves were plotted for the different vitamins (Fig. 5) and showed excellent $\mathrm{R}$ values for the different vitamins, which indicates the applicability of the proposed method with high sensitivity. 

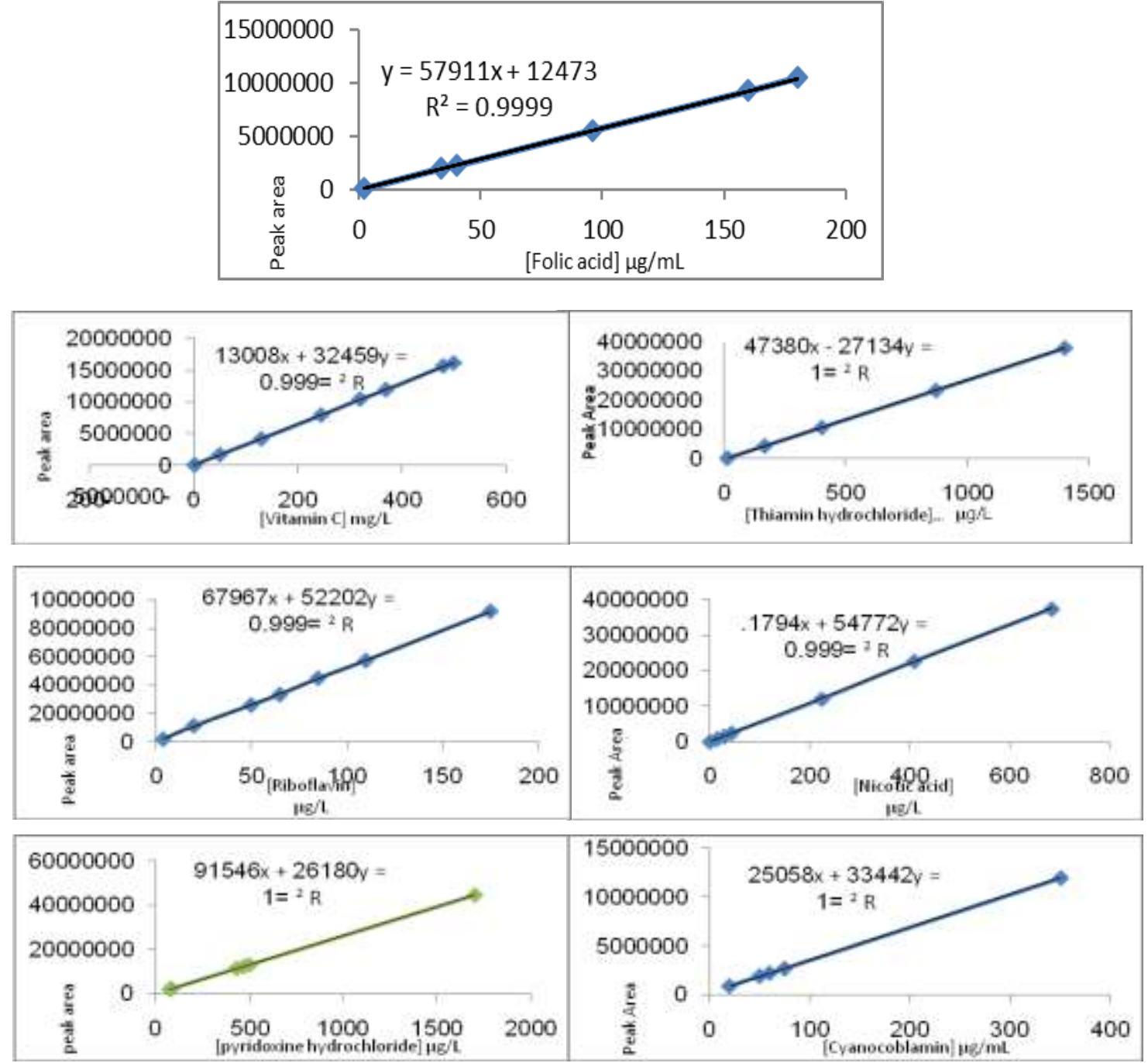

Fig. (5): calibration curve for water soluble vitamins.

Also, method validation studies were performed by measuring basic parameters such as precision, accuracy, linear region, limits of detection (LOD), and quantification (LOQ) $\mathrm{ICH}$ Harmonized, and recovery (Tables $3 \& 4$ ). 
Ahmad M. Farag et al.

Table (3): Method of validation for determination of different vitamins with the proposed method.

\begin{tabular}{cccccc}
\hline Vitamin & Rt $(\mathbf{m i n})$ & LOD & LOQ & Accuracy & Linear range \\
\hline $\mathbf{B}_{\mathbf{1}}(\boldsymbol{\mu g} / \mathbf{L})$ & 28.5 & 4.795 & 14.532 & $101.62 \pm 3.60$ & $12-1400$ \\
$\mathbf{B}_{\mathbf{2}}(\boldsymbol{\mu g} / \mathbf{L})$ & 26.0 & 2.412 & 7.3084 & $99.64 \pm 5.04$ & $4-175$ \\
$\mathbf{B}_{\mathbf{3}}(\boldsymbol{\mu g} / \mathbf{L})$ & 8.0 & 5.117 & 15.505 & $99.78 \pm 2.18$ & $1.6-685$ \\
$\mathbf{B}_{\mathbf{6}}(\boldsymbol{\mu g} / \mathbf{L})$ & 12.2 & 4.921 & 14.912 & $100.23 \pm 0.64$ & $75-3150$ \\
$\mathbf{B}_{\mathbf{9}}(\boldsymbol{\mu g} / \mathbf{L})$ & 22.0 & 1.064 & 3.225 & $98.04 \pm 5.66$ & $2-540$ \\
$\mathbf{B}_{\mathbf{1 2}}(\boldsymbol{\mu g} / \mathbf{L})$ & 24.5 & 8.380 & 25.395 & $100.30 \pm 1.98$ & $20-350$ \\
Vit. $\mathbf{C}(\mathbf{m g} / \mathbf{L})$ & 5.1 & 3.230 & 10.768 & $100.22 \pm 2.14$ & $1.5-500$ \\
\hline
\end{tabular}

Detection limits of vitamins $\left(\mathrm{B}_{1}\right.$, $\mathrm{B}_{2}, \mathrm{~B}_{3}, \mathrm{~B}_{6}, \mathrm{~B}_{9}, \mathrm{~B}_{12}$ and $\mathrm{C}$ ) were 4.795 , 2.412, 5.117, 4.921, 1.06, 8.380 $\mu \mathrm{g} / \mathrm{L}$ and $3.230 \mathrm{mg} / \mathrm{L}$, respectively, where the quantification limits were 14.532, 7.308, $15.505,14.912,3.225,25.395 \mu \mathrm{g} / \mathrm{L}$ and $10.768 \mathrm{mg} / \mathrm{L}$, respectively, with recovery\% in the range of $98-102 \%$.

Table (4): Concentration of Water soluble vitamins compounds in honey bee under study.

\begin{tabular}{|c|c|c|c|c|c|c|c|}
\hline honey vitamins & $\begin{array}{c}\mathrm{B}_{1} \\
\mathrm{mg} / \mathrm{kg}\end{array}$ & $\begin{array}{c}\mathrm{B}_{2} \\
\mathrm{mg} / \mathrm{kg}\end{array}$ & $\begin{array}{c}\mathrm{B}_{3} \\
\mathrm{mg} / \mathrm{kg}\end{array}$ & $\begin{array}{c}\mathbf{B}_{6} \\
\mathrm{mg} / \mathrm{kg}\end{array}$ & $\begin{array}{c}\mathrm{B}_{9} \\
\mathrm{mg} / \mathrm{kg}\end{array}$ & $\begin{array}{c}B_{12} \\
\mu g / 100 g\end{array}$ & $\begin{array}{c}\mathrm{C} \\
\mathrm{mg} / \mathrm{kg}\end{array}$ \\
\hline Spring flowers & ------- & $2.3 \pm 0.4$ & ---------- & $3.73 \pm 0.9$ & $1.98 \pm 0.9$ & $0.83 \pm 0.07$ & $0.6 \pm 1.31$ \\
\hline Sweet marjoram & $2.9 \pm 0.65$ & $3.5 \pm 1.02$ & $2.83 \pm 0.9$ & $3.01 \pm 0.5$ & $2.39 \pm 3.6$ & $4.6 \pm 1.66$ & $1.4 \pm 3.5$ \\
\hline Sun flower & $4.3 \pm 0.81$ & $1.5 \pm 0.55$ & $2.5 \pm 0.55$ & $1.9 \pm 0.45$ & $1.0 \pm 2.87$ & $1.026 \pm .43$ & ---- \\
\hline Clover flowers & $1.18 \pm 0.59$ & -------- & $1.8 \pm 0.41$ & $1.73 \pm 0.6$ & $0.99 \pm 1.5$ & $0.6 \pm 0.02$ & $2.8 \pm 2.9$ \\
\hline Citrus fruits & $0.98 \pm 0.47$ & $1.66 \pm 0.22$ & $2.86 \pm 1.0$ & $2.9 \pm 0.95$ & $1.5 \pm 2.7$ & $1.8 \pm 0.61$ & $3.7 \pm 4.02$ \\
\hline Black seed & $2.1 \pm 0.74$ & $1.06 \pm 0.35$ & $4.1 \pm 1.44$ & $1.9 \pm 0.64$ & $0.74 \pm 1.8$ & --------- & ----------- \\
\hline
\end{tabular}

Seven water soluble vitamins were measured in different types of honey sample which showed various concentrations (Table 4). The highest level for vitamin $\mathrm{C}$ in citrus fruits honey was $3.75 \mathrm{mg} / \mathrm{kg}$, the highest level for vitamin $\mathrm{B}_{1}$ in sunflower honey was $4.3 \mathrm{mg} / \mathrm{kg}$, the highest level for vitamin $\mathrm{B}_{2}$ in sweet marjoram honey was $3.5 \mathrm{mg} / \mathrm{kg}$, the highest level for vitamin $B_{3}$ in black seed honey was $4.1 \mathrm{mg} / \mathrm{kg}$, the highest level for vitamin $\mathrm{B}_{6}$ in spring flower honey was $3.73 \mathrm{mg} / \mathrm{kg}$, the highest level for vitamin $\mathrm{B}_{9}$ in sweet majoram honey was 2.39 $\mathrm{mg} / \mathrm{Kg}$ and the highest level for vitamin $\mathrm{B}_{12}$ in sweet majoram honey was 4.6 $\mu \mathrm{g} / 100 \mathrm{gm}$. While the lowest levels for vitamin $\mathrm{C}$ in spring flowers honey was 0.6 $\mathrm{mg} / \mathrm{kg}$, for vitamin $\mathrm{B}_{1}$ in citrus fruits was $0.98 \mathrm{mg} / \mathrm{kg}$, for vitamin $\mathrm{B}_{2}$ in black seed honey was $1.06 \mathrm{mg} / \mathrm{kg}$, for vitamin $\mathrm{B}_{3}$ in clover flowers honey was $1.8 \mathrm{mg} / \mathrm{kg}$, for vitamin $\mathrm{B}_{6}$ in clover flower honey was $1.73 \mathrm{mg} / \mathrm{kg}$, for vitamin $\mathrm{B}_{9}$ in black seed honey was $0.74 \mathrm{mg} / \mathrm{kg}$ and for vitamin $B_{12}$ in clover flowers honey was $0.6 \mu \mathrm{g} / 100 \mathrm{~g}$. In a study of (19) the highest level in honey samples for vitamin $\mathrm{C}$ was 5.8 $\mathrm{mg} / \mathrm{Kg}$ in eucalyptus honey, $\mathrm{B}_{2}$ was 9.2 $\mathrm{mg} / \mathrm{Kg}$ in thistle honey, $\mathrm{B}_{3}$ was $27.8 \mathrm{mg} / \mathrm{kg}$ in thistle honey and $\mathrm{B}_{6}$ was $7 \mathrm{mg} / \mathrm{kg}$ in eucalyptus honey.

\section{Conclusion}

For quick, simultaneous and simple determination of seven water-soluble vitamins $\left(\mathrm{B}_{1}, \mathrm{~B}_{2}, \mathrm{~B}_{3}, \mathrm{~B}_{6}, \mathrm{~B}_{9}, \mathrm{~B}_{12}\right.$ and $\left.\mathrm{C}\right)$ in Egyptian honey, gradient RP-HPLC method was developed and validated in terms of linearity, sensitivity and accuracy. Detection limits were 4.795, 2.412, 5.117, 4.921, $1.06,8.380 \mu \mathrm{g} / \mathrm{L}$ and $3.230 \mathrm{mg} / \mathrm{L}$, 


\section{Determination of water soluble vitamins in Egyptian Honey by RP-HPLC}

respectively, and quantification limits of $14.532, \quad 7.308,15.505,14.912,3.225$, $25.395 \mu \mathrm{g} / \mathrm{L}$ and 10.768 , for vitamins $\mathrm{B}_{1}$, $\mathrm{B}_{2}, \mathrm{~B}_{3}, \mathrm{~B}_{6}, \mathrm{~B}_{9}, \mathrm{~B}_{12}$ and $\mathrm{C}$, respectively, with good linearity and good correlation coefficients $\left(\mathrm{R}^{2}\right)$. Mean recoveries obtained were in the range of $98-102 \%$ which ensures the success of the method. The extraction and separation using highperformance liquid chromatography (HPLC) exhibited high response, sensitivity and fast separation. The overall concentration of the seven analytes never increased $40 \mathrm{mg} / \mathrm{kg}$ and often appeared to be significantly dependent on the type of honey. According to these recommendations, the Sweet marjoram honey is good source of vitamins $\mathrm{B}_{2}, \mathrm{~B}_{6}$ and $\mathrm{B}_{12}$, and sun flower, Black seed, spring flowers and citrus honey are good sources of vitamin B1, B3, B6 and vitamin $\mathrm{C}$, respectively.

\section{REFERENCES}

Abdel-Haleem, F.M.; Badr, I. and Rizk, M.S. (2016). Potentiometric anion selectivity and analytical applications of polymer membrane electrodes based on novel $\mathrm{Mn}$ (III)and Mn (IV) Salophen Complexes. Electroanal., 28 (12): 2922.

Abdel-Haleem, F.M.; Saad, M. and Rizk, M.S. (2016). Development of new potentiometric sensors for the determination of proguanil hydrochloride in serum. J. Chin. Chem. Lett, 27(6): 857

Ajibola, A.; Idowu, G.; Amballi, A.; Oyefuga, O. and Iquot, I. (2007). Honey and its Anti-Inflammatory, Anti-Bacterial and Anti-Oxidant Properties, J. Biol. Sci. Res.; 2: 67

Ajibola, A.; Chamunorwa, J.P. and Erlwanger, K.H. (2012). The nutritional profiles, including its use in infant and children feeding reported in different literatures. Nutrition \& Metabolism 9: 61. DOI: $10.1186 / 1743-7075-9-61$
Al-Waili, N. and Haq, A. (2004). Effect of honey on antibody production against thymus-dependent and thymus-independent antigens in primary and secondary immune response, J. Med. Food, 7(4): 491.

Buhlmann, P.; Pretsch, E. and Bakker, E. (1997). Carrier-Based IonSelective Electrodes and Bulk Optodes. $1 . \quad$ General Characteristics. Chem. Rev., 97(8): 3083-3132.

Chepulis, L. and Compl, J. (2007). The Effects of Honey Compared With Sucrose and a Sugar-free Diet on Neutrophil Phagocytosis and Lymphocyte Numbers after Longterm Feeding in Rats. J. Med., 4 (1): 1 .

Ciulu, M.; Solinas, S.; Floris, I., Panzanelli, A.; Pilo, M.I.; Piu, P.C.; Spano, N. and Sanna, G. (2011 RP-HPLC determination of water-soluble vitamins in honey, Talanta, 83: 924.

Ekinci, R. and Kadakal, C. (2005). Determination of seven watersoluble vitamins in tarhana, a traditional Turkish cereal food, by high - performance liquid chromatography. Acta Chrom., 15(15): 289.

Fotsing, L.; Fillet, M. and Bechet, I. (1997). Determination of six watersoluble vitamins in a pharmaceutical formulation by capillary electrophoresis. J. Pharm. Biomed. Anal, 15: 1113.

ICH Harmonized (2005). Tripartite Guide Line Validation analytical procedures: text and methodology Q2 (R1), Parent Guidelines on Methodology.

Indyk, H.; Persson, B.; Caselunghe, M.; Filouzi, E. and Wollard, D. (2002). Determination of vitamin B12 in milk products and selected foods by optical biosensor proteinbinding assay: method comparison, J. AOAC Intl., 85: 72. 
Ahmad M. Farag et al.

Lioyd, R.; Joseph, J. and John, W. (2011). Introduction to Modern Liquid Chromatography, $3^{\text {rd }}$ ed. (Wiley).

Marszall, M.L.; Lebiedzinska, A.; Czarnowski, W. and Szefer, P. (2005). High-performance liquid chromatography method for the simultaneous determination of thiamine hydrochloride, pyridoxine hydrochloride and cyanocobalamin in pharmaceutical formulations using coulometric electrochemical and ultraviolet detection. J. Chrom. A, 1094 (1-2): 91

Mimica, D.; Bedioui, F. and Zagal, J.H. (2002). Reversibility of the Lcysteine/L-cystine redox process at physiological $\mathrm{pH}$ on graphite electrodes modified with coenzyme B12 and vitamin B12. Electrochim. Acta, 48: 323

Molnar, I. (1996). Validation of robust chromatography methods using computer - assisted method development for quality control, LC-GC. Int., 9: 800.

Ramla, A. (2016). Determination of Water Soluble Vitamins [(B group: B1, B2, and B6) by RP- HPLC. J. Chem. and Materials Res., 8(10): 8 Revanasiddappa, H. and Veena, M. (2008). Sensitive spectrophotometric method for the determination of ascorbic acid E. J. Chem., 5: 10-15

Rizk, M.S. and Abdel-Haleem, F.M. (2010). Plastic membrane electrodes for the determination of flavoxate hydrochloride and cyclopentolate hydrochloride. J. Electrochim. Acta, 55 (20): 5592

Rizk, M.S.; Badr, I. and Abdel-Haleem, F.M. (2017). Potentiometric Determination of Ciprofloxacin in Physiological Fluids Using Carbon Paste and Nano Composite Carbon Paste Electrodes. Electroanal., 29 (4): 1172.

Rokayya, S.; Yang, L.; Baokun, Q., Hengnan, W.; Qiaozhi, Z.; Feifei, H.; Ying, M.; Jing, J. and Lianzhou, J. (2014). HPLC Analysis of Water-Soluble Vitamins (B2, B3, B6, B12, and C) and Fat-Soluble Vitamins (E, K, D, A, and $\beta$-Carotene) of Okra. J. Chem., 2014:6. doi.org/10.1155/2014/831357

Rucker, R.; Suttie, J.; McCormick, V. and Machlin, L. (2004). Hand Book of Vitamins, $3^{\text {rd }}$ ed. (Marcel Dekker).

Rucker, R.; Suttie, J. ; McCormick, V. and Machlin, L. (2007). Hand Book of Vitamins, $4^{\text {th }}$ ed. (Taylor and Francies Group, LLC).

Schramm, D.; Karim, M.; Schrader, H.; Holt, R.; Cardetti, M. and Keen, C. (2003). Honey with high levels of antioxidants can provide protection to healthy human subjects. J. Agric. Food Chem., 51: 1732.

Semba, R. (2012). The discovery of the vitamins. - NCBI. Int. J. Vitam. Nutr. Res., 82(5): 310-5. doi: 10.1024/0300-9831/a000124. 
تقدير الفيتامينات الذائبة في الماء في عسل المصري باستخدام الكروماتو غرافيا السائلة عالية الأداء

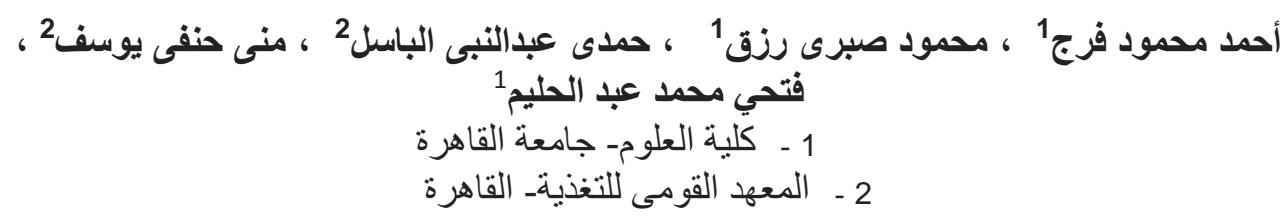

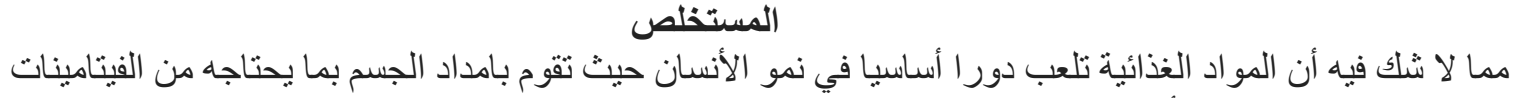

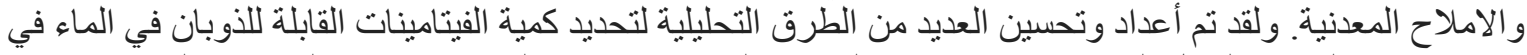

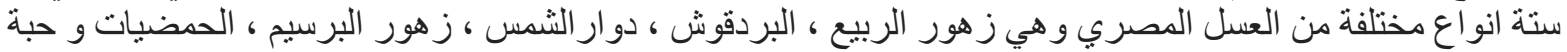

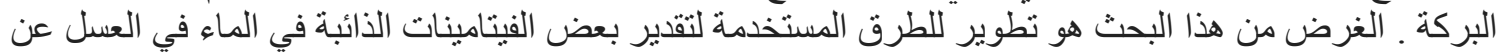

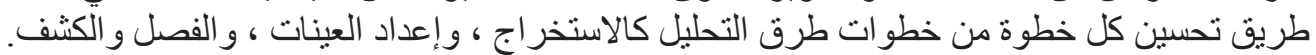

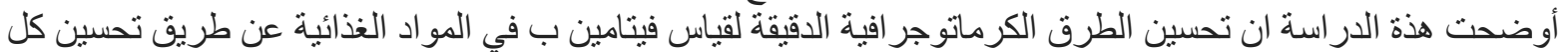

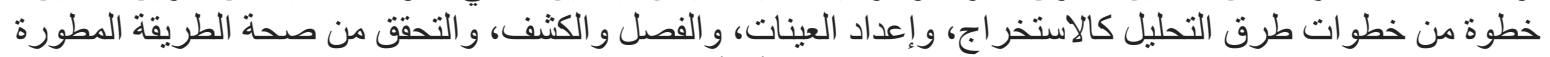

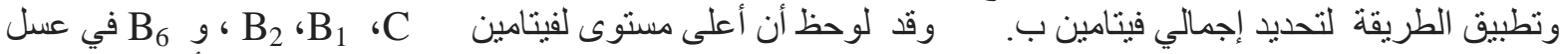

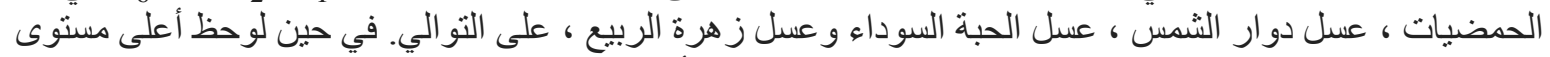

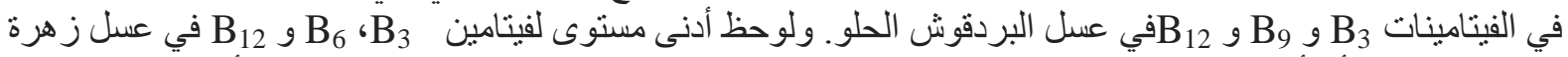
البرسيم في حين أن أدنى مستوى في الفيتامينات

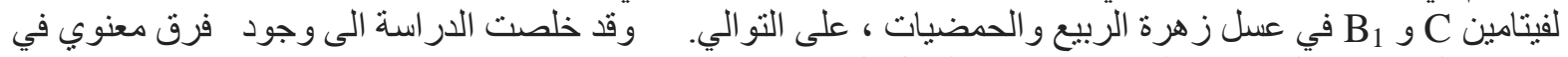
محتوى الفيتامينات ألذائبة في الماء حسب الربع ونوع العسل المصري. 